\title{
Coastal and Ocean Clean up Activities at Tunda Island to Support Local Awareness in Underwater Tourism Conservation
}

\author{
Yulia Lintangkawuryan, Sst.Par., M.Par \\ Sekolah Tinggi Pariwisata Trisakti, Jakarta, Indonesia \\ Email: yulialintang@stptrisakti.ac.id
}

\begin{abstract}
Underwater and marine tourism which has been improving and whose enthusiasts have been growing rapidly in recent years is an important component of alternative tourism. This include the activities being done with the aims of witnessing the beauties, hunting, taking photos, the ecology and the archaeology of underwater analysing or finding out the human being's boundaries by improving the physical and psychological skills of men. Tunda Island is a small island is located in Java Sea, in the northern of Banten Gulf. The problem of waste in the tourist area is still a major problem for the development of local tourism. Coastal and ocean clean action was introduced and conducted direct action at the location. There are several important things that are obtained from the implementation of this activities. First, the concepts and activities are able to increase the understanding of citizens and tourists about the importance of coastal cleanliness. Second, these activities can increase the knowledge and awareness of the residents to some types of polluters around the coast. Third, the need for program sustainability and addition of hygiene facilities at the beach location.

The history and development of Indonesia are intimately linked to the sea. The region possesses a rich underwater cultural and natural heritage which reflects its identity and should be protected for future generations. It is getting more and more famous with its underwater richness. By providing visual attractiveness, the tourists related to underwater tourism will pay attention to Indonesia and underwater tourism will contribute much to the economy of the region.
\end{abstract}

Key Words: Tourism, Underwater Tourism, Indonesia, Freediver, Freediving, Mermaid, Coastal Clean Up, Ocean Clean Up

\section{INTRODUCTION}

Geographically, the State of Indonesia inherited a vast archipelagic region compared to other countries in the world. It should be understood that the territorial waters of Indonesia only covers $100,000 \mathrm{~km} 2$ when Indonesia declared independence in 1945 (calculated along 3 miles from baselines). In 1957 the government fo Indonesia developed the concept of archipelagic state which calculate the territorial waters along the 12 miles from the baselines. When this idea was then recognized internationally in 1982 (UNCLOS 1982), the territorial waters of Indonesia became more greater, wich is 3 million $\mathrm{km} 2$. In addition, Indonesia also have sovereign rights over natural resources outside of the teritorial waters as far as 200 miles from the baseline, which is in the Exclusive Economic Zone and Continental Shelf. Since then the soverignity of Indonesia to the sea area increase again to about

$3,000,000 \mathrm{~km} 2$. If the water areas are added to the land areas, which is an area of more than

2,000,000 miles, then the total areas increase again to around 8 million $\mathrm{km} 2$ (Djalal 2008, Martindas et al. 2007). Indonesian territory consists of over 17 thousand islands stretching from west to east along the $6400 \mathrm{~km}$ and from north to south along the 2,500 km. If compared with Europe, its length is equal to Europe drawn from Ireland in the west to Kazakhstan in the East, and from Latvia in the north to Turkey in the south.

As is the case in many countries of the world, tourism is one of the largest and dynamic industries that support and even drive the country's economics in Indonesia. Underwater tourism is one of the most popular tourism activities of the recent years. It is rapidly developing around the world due to such characteristics as applicability in all seasons, supportiveness, and environmentally protective. With its beauty bays of varying sizes as well as natural, historical, and cultural 
treasures, Indonesia is one of the most beautiful holiday destinations of not only the South East Asia but also the entire world. With its climate conditions, adequate tourism infrastructure, countless bays of unrivalled beauty, clear and clean waters, Indonesia is ideally located to establish a coastal and underwater tourism centre. The problems that often occur in the coastal and underwater areas are environmental pollution that will impact on the destruction of organisms living in the area. Wastes in the coastal environment can poison phytoplankton which can eventually decrease the fertility of aquatic (Hutabarat in Awaluddin et al., 2011). Some of the trash that is found in those areas are garbage in plastic form.

\section{LITERATURE REVIEW}

Tunda Island is a small island is located in Java Sea, in the northern of Banten Gulf. Administratively, the island is included in the district of Serang, Banten. Tunda Island is a vast island of about 300 acres. In 2007, the population reached 3,000 people Defer Island. Administratively, In Tunda Island there is one village, which is Wargasara Village. The village name is defined as a village that citizens obey the law,Wargasara is a village name given by the late community leader at that moment called H. Mohammad Toha, who served as chief of the village. This village consists of two hamlets namely the West Village and the East Village. The common jobs for villagers are fishing, planting crops, and a small part as the middleman.

Tunda Island actually already a very attractive tourism objects. The beauty of the beach and sea further yet unexplored. Though sailing activities with a view of the sea and dolphins, fishing, snorkeling, diving, see the sunset and sunrise is an attractive tourist potential. Only a few investors investing or conducting business in the tourism industry in Tunda Island. So that local governments should continue to explore the potential of this exciting unspoiled.

There are certain times the beach is busy visited by domestic tourists, like in every school holiday or after the holiday. The large number of tourists will of course bring along the impact, in the form of pollution of coastal and underwater areas. this problem is also added with the existence of local waste treatment from the community that is less adequate due to lack of access. As far as the author's knowledge, there is not much information as well as a study of the level of coastal pollution at the site. This is confirmed by the fact that about $80 \%$ of respondents also stated that the condition of the beach is not clean. In addition, Handaka et al (2007) has also shown that people's perception is quite high on coastal cleanliness, but this is constrained by the facilities and support of the local government. The involvement of various parties including the government will greatly support the cleanliness of the beach so that it will create a comfortable coastal environment and can attract tourists.

In terms of underwater cultural heritage relics, Indonesia may be one of the richest countries in Asia. Unfortunately, its management still has not done in an effective and integrated manner so that their utilization was not optimal. If improvements of the management are not taken immediately then the underwater cultural heritage will be endangered. For more understanding of the problem of the management of the underwater cultural heritage in Indonesia, the following list of issues should be noted.

One effort that is expected to support coastal cleanliness is the pro-active efforts of the community element. People in this case are local people as well as tourists. Handaka et al (2007) suggested that routine work efforts to clean the beach as one step that can be taken to preserve the coastal environment. This is in line with various activities or actions undertaken by some communities in maintaining this coastal environment. This time author following the Coastal and Ocean Cleanup Activities that being held by Joint communities that consist of Indonesia Mermaid Pod, and Apnea Freak. Those three communities has the same interest in underwater sport called freediving and of course share the same concern to keep the ocean as their playground, clean and healthy. This activity is expected to reduce the impact of waste contamination in the Tunda Island, so that the ecosystem sustainability on the beach and ocean is maintained

According to Hutabarat and Evans (1985), these coastal and coastal pollution problems will have an impact on the destruction of living organisms in the area. For example, garbage or other contaminants can poison phytoplankton which can ultimately decrease the fertility of a waters. Further Hutabarat and Evans (1985) conveyed some coastal pollutants and oceans to watch out for, including 
oil pollution, heavy metal pollution, pesticides and garbage. This type of pollution is the main problem in some coastal tourist sites in Indonesia. Efforts to maintain cleanliness in the coastal areas will be very important.

This coastal cleanup activity is part of the effort from the citizens of the world to care for the cleanliness of the coastal environment. This activity is a mass movement and involves volunteers to carry out net coastal activities by survey method, usually done in the same period. This activities also is a conjuction with One Island One Voice, one of the biggest clean up activities in Indonesia with Bali as the centre island and open for any other island who want make a similar activity on the same date which is February $24^{\text {th }}$. So this is a movement of national coastal cleanup which is done simultaneously in various coastal areas around Indonesia. This activity also provides an opportunity for the community, tourists and volunteers from Indonesia to participate in this coastal hygiene campaign.

This is an effective concept of activity to raise awareness communities against coastal pollution through direct experience of surveys and taking direct waste (Ohkura and Kojima, 2007). Based on Ohkura and Kojima (2007), these activities can provide participants with the following challenges and knowledge:

1. The source of coastal pollution comes from the waste generated from the daily lives of people who are discharged through rivers or other channels.

2. Everyone produces waste that is easily visible and already considered be advised.

3. The best solution is to develop a caring and community community

reliable to prevent such pollution and to develop the community to have a recycling orientation.

\section{METHODS}

\section{A. Data}

Tunda Island has an alarming problems with garbage around coastal beaches also some of the shallow ocean area. This is due to the increase in tourism activity beach at that location. Obviously this is the unavoidable effects from the tourism development activities there. An alternative solution to the waste problem in Tunda Island will be the author's main focus. One alternative solution that can be done is a net beach activity that can involve many people. This activity also has the potential to increase citizens' awareness of the importance of cleanliness in the beach and ocean coastal area. In addition, installation of garbage cans at the tourist sites will also help reduce the volume of waste on the coast. The communities who being involved in this program made several meeting with the local side and government to do the brainstoming and create the best plan for the program details. Here is the detail of the event:

- Venue : Tunda Island, Serang, Banten

- Day/ Time : : Saturday, 24th February 2018.

- Packaging : The volunteer and the local people will make a joint program consist of coastal and ocean cleanup also make a forum and workshop to find an alternative solution for the waste treatment.

\section{B. Method}

The method used in the implementation of the activities is in accordance with the concept as described by Awaluddin (2011). The method that will be used is following the International Union Concervancy of Nature (IUCN) standard with a standard data table containing the contaminants obtained in the activity location. The polluted data obtained will then be analyzed together with the Ocean Conservancy international institution. The net type of beach that will be done is in the form of shore cleanup (Ocean Concervancy, 2011) which includes the highest tide area near the dune area that is not affected by the tidal effects of sea water.

Participants consisted of tourists, representatives of each hamlet and local people willing to volunteer. Prior to carrying out clean coastal activity, participants will be given a 
preliminary explanation of the technical implementation of clean beaches, including inform pollutants that will be cleaned and done data collection. In addition, participants were also given sheets of questionnaires as pre-tests before the activities were carried out.

After that, the participants will be divided into several small groups of 4 people and divided into several points of clean coastal areas. Each of the three small groups will sweep an area of $500 \mathrm{~m}$. Each group will be accompanied by 2 bioball garbage bags, standard clean beach cards, and gloves. Each group noted the contaminants as in the standard card. When completed, each group collects a plastic bag containing the contaminants at each point of the designated area. Prior to being brought by a garbage collector team from a local village government, the plastic container containing the waste will be weighed. Then the postactivity questionnaire is then circulated to the participants and the community to find out the feedback of the activity.

\section{RESULTS AND DISCUSSION}

\section{A. Pre- Result}

To increase the knowledge of the participants, the authors conducted training in the form of general explanation and technical method of International Coastal Cleanup (ICC) activity. There are 40 participants who attended the explanation consisting of participants from Apnea Freak and Indonesia Mermaid Pod, village officials, hamlet representatives, residents, and the owners of stalls on the coast. The participants also received a short brochure containing the concept of ICC as well as technical implementation.

Based on the interviews and questionnaires given to the participants before the activity, $79 \%$ of participants did not know how to clean beach, while $21 \%$ stated already know how. Another interesting thing is that participants who know how to clean beach activities is limited to sweeping the coast and then burn it directly on the beach. The owners of stalls around the beach is what always clean the beach that is still the area around the shop. In addition, the absence of garbage places in the tourist area is also very regrettable by the participants. This is evident from about $90 \%$ of participants suggested to be provided the trash at tourist sites. As well as about $5 \%$ others suggest to do beach clean-up activities.

\section{B. Result}

The participants were given a post-activity questionnaire to find out the responses and feedback from the participants. The results obtained that $100 \%$ of participants get knowledge of the importance of coastal hygiene and the contaminants present. As many as $80 \%$ of participants suspect that the waste generated at that location sourced from tourists, while another $10 \%$ are thought to be from residents and nearby stalls and the rest are thought to come from other sources.

Meanwhile, from the existing quantity of pollutants, as much as $87.5 \%$ states have been reduced visibly at the location after the ICC activities and another $12.5 \%$ said no less. This indicates that the implementation of ICC is still incomplete, so there are still pollutants on site activity even in small quantities. So all the participants expressed their support to be done ICC routinely in that location. In addition, the participants also suggested that the trash can be provided at the tourist sites. This is revealed because the lack of means of cleanliness such as the trash earlier, so it would be difficult for wiatawan to dispose of garbage.

\section{Discussion}

Without any attempt to do the preservation of underwater cultural heritage, this fragile cultural heritage will be endangered in the near future. If this happens, public access to cultural heritage is also difficult to obtain. Commercialization of underwater cultural heritage is a form of marginalization of cultural asset that is very detrimental in terms of public interest, either for the purpose of education, science and recreation. This situation will be worsen if the government did not comitt seriously, especially if the government keep trying to sell them as commodities to increase state revenue in a short time with a reason to overcome poverty. Real economic gains over long term can still be pursued and does not need to sell. This can be done if we developed 
integrated management system. In this respect, at least we have to consider four key aspects in managing underwater cultural heritage, i.e. (1) exploration, (2) database development, (3) protection, and (4) utilization.

Exploration of underwater cultural heritage, basically can be done on the basis of two considerations, namely the practical and scientific or theoretical. Practical consideration usually involve removal action of underwater site or other intervention carried out in emergency situations, for example for rescue purposes or for the prevention of sites from destroyed or annihilated. Another practical consideration is that action can possibly provide long-term benefits for society at large, e.g., for display in museums as an example of masterpiece that can be enjoyed by the public. The exploration undertaken on the basis of scientific consideration is planned actions intended to address the problems in science that need to be answered.

Database is an important source to determine the next programs, namely the protection and utilization. Included in the protection aspects are conservation, maintenance, and security. While aspects of utilization include academic (research, and education), ideologic (e.g. planting the values of nationality), economic (as an object of tourist attraction) or a combination of these aspects. It should be emphasized that not all sites of underwater cultural heritage can be utilized because there is a possibility that a number of sites should be closed to public access because it has the potential to harm, such as the shipwreck which contain toxic liquid or explosives materials.

It should be emphasized that economical utilization should not be directed at short-term goals by selling, but directed at the long-term goals with respect to the principle of sustainability. From the perspective of sustainable management, utilization is basically one aspect of preservation. One paradigm that is used as a guide for future management of cultural

heritage is to strive for the utilization of cultural heritage for the benefit of the masses while still holding the principle of conservation.

If this principle is applied in the utilization of underwater cultural heritage as a marine tourist attraction, the conservation principle is not only imposed on underwater cultural heritage, but also on the natural heritage around the site, such as coral reef ecosystems.

Another effort that could be carried out is to encourage public awareness on the important of our fragile cultural heritage to be protected as long as we could for the benefit of our present and future generation.

\section{REFERENCES}

Ardiwidjaya, Robby. (2009). Pelestarian Peninggalan Bawah Air: Wisata Bahari sebagai Alat Pelestari. Varuna, Vol III/2009, h. 35-50.

Awaluddin, M.Y., (2011). Introduksi konsep bersih pantai (Coastal Cleanup) di Pantai Sindangkerta, Kecamatan Cipatujah, Kabupaten Tasikmalaya. Jurnal Harpodon Borneo. September 2011.

Dahuri, R., J. Rais., S.P. Ginting, M.J. Sitepu. (1996). Pengelolaan sumberdaya wilayah pesisir dan lautan secara terpadu. Pradnya Paramita. Jakarta.

Handaka, AA., I. Riyantini, M.Y. Awaluddin. (2007). Kepedulian Masyarakat Terhadap pencemaran di wilayah pesisir Pameungpeuk Kabupaten Garut. Jurnal Akuatika. FPIK Unpad.

Hutabarat, S. dan Evans S.M. (1985). Pengantar Oseanografi. UI Press. Jakarta

Hunter, Jack. (2001). Heritage or Hazard? The Oil Tanker Montebello and Its Potentially Dengerous Cargo. Dalam Ruppe, Carol V. dan Janet F. Barstad (ed). h. 727-736.

Junaedi, Didien. (2007). Konsep Pengembangan Wisata Bahari di Indonesia. Dalam Deklarasi Juanda: Sejarah Kewilayahan Indonesia. Disunting oleh Kasijanto Sastrodinomo. Jakarta: Direktorat Geografi Sejarah, Ditjen Sejarah dan Purbakala, Kementrian Budpar, h.230-236. 
Jambeck, J.R., R. Geyer, C. Wilcox, T. R. Siegler,M. Perryman, A. Andrady, R. Narayan, K. L. Law. (2015). Plastic waste inputs from land into the ocean. Science, 347 (6223):

768-771.

Lombard, Denis. (1996). Nusa Jawa: Silang Budaya. Vol. 1 (Batas-batas pembaratan), Jakarta: Gramedia.

Ocean Conservacy. (2011). Tracking trash 25 years of action for the Ocean. Organisation Report. 43pp

Ohkura, Y. and Kojima, A., (2007). International Coastal Cleanup Campaign Coordinated by JEAN in Japan Present state and future prospects. The $2^{\text {nd }}$ NOWPAP Workshop on Marine Litter. 28-29 March

Ocean Concervancy. (2011). Tracking trash 25 years of action for the Ocean. Organisation Report. 43pp.

Provinsi Jawa Barat. (2011). http://www.jabarprov.go.id/index.php/subMenu/98 diakses tanggal 2 Agustus 2011. 